\title{
TIIE EVALUATIQN OF THE RESIDUAL EFFECT OF PHOSPHATE ON PERMANENT PASTURES
}

\author{
J. KARLOVSKY, Scientific Officer, Rukuhia Soil Research \\ Station, Hamilton
}

Phosphatic fertilisers applied over a period exert an effect which may last for a considerable time, depending on the amount of fertiliser used and the soil type. Thus, for instance, at Hoosfield, England, phosphatic fertilisers applied before 1911 continued to exert a marked influence as late as 1949. In field trials on a farm in Seine et Oise, France, phosphates applied before the Second World War, in excess of removals, have shown an after-effect up till 1952.

Many New Zealand soils have received appreciable amounts of phosphates -over the last 30 years- and the evaluation of the residual effects of the accumulated phosphorus is becoming important. Over the past few years many trials have been carried out at Rukuhia Soil Research Station to study some aspects of phosphate residual effect. The main object of this work has been to obtain some indication of the residual value of past phosphate dressings and to find out just how serious is the effect on pasture production of discontinuing phosphate topdressings.

\section{Residual Effects of Phosphatic Fertilisers on Pasture Production and Soil Test}

Trials on three main Waikato soil types measured the decline in pasture production and soil test values for phosphorus after topdressing ceased. The pasture yields on plots on which topdressing was stopped were expressed as a percentage of the maximum yield obtained in the same fields on plots adequately treated with phosphate. Soil phosphorus in O-3 in. layer was determined by Truog's extractant $(0.002 \mathrm{~N}$ sulphuric acid buffered with ammonium sulphate) and $\mathrm{P}$ units are parts $\mathrm{P}$ per 50,000,000 of soil extract.

Trial 1: This was conducted on Hamilton clay loam, which is a low phosphate fixing soil type. When the trial began in 1952 the soil test for phosphorus was $10.5 \mathrm{P}$ units. The area was rotationally grazed by sheep. Pasture production was measured by the "frame" technique (Lynch).

Fig. 1 shows the annual pasture production on plots which received no further phosphate application after 1952, relative to maximum production obtained on plots which had $6 \mathrm{cwt}$ per acre 


\section{RELATIVE YIELD}
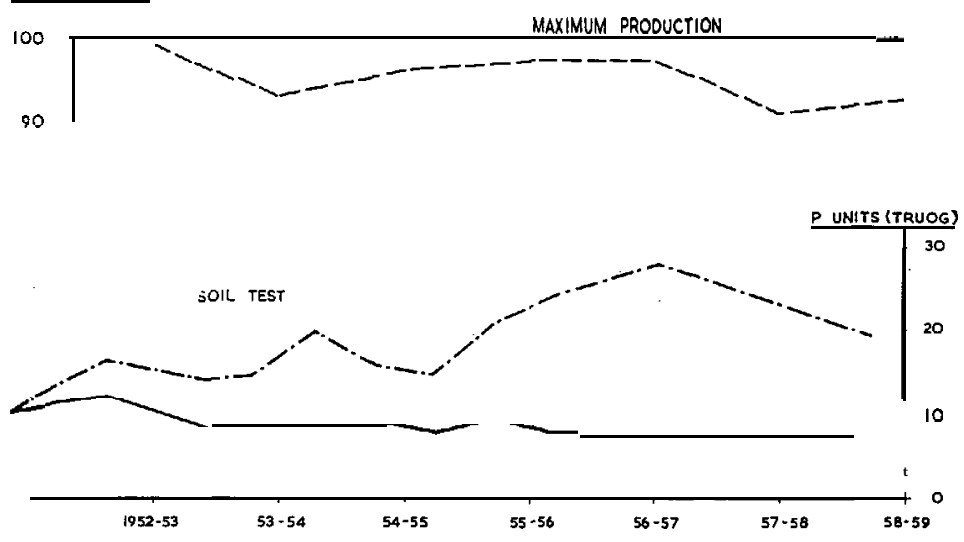

Fig. 1. ---- Annual pasture production on Hamilton clay loam after the cessation of topdressing relative to maximum production equal to 100 . - Soil test for phosphorus on plots on which topdressing has been discontinued.

,,--- Soil test for phosphorus on plots with maximum yield.

of superphosphate annually from 1952 onwards. The soil tests for phosphorus for both topdressed and untopdressed plots are also shown.

For the first five years pasture production of the untopdressed area fluctuated between 93 and 99 per cent of the maximum production, but in the sixth and seventh year it was 91 and 92 per cent respectively.

The decline in the soil test of the untreated soils was very gradual, and after seven years it had decreased by $4 \mathrm{P}$ units. The test on the topdressed area increased from 10.5 to about $20 \mathrm{P}$ units after four annual applications of $6 \mathrm{cwt} /$ acre superphosphate, and it then fluctuated above the level of 20 units for the following three years.

Trial 2: This was a similar trial on medium phosphate fixing Ohaupo silt loam on which the soil test level for phosphorus was $9 \mathrm{P}$ units in 1952.

As shown in Fig. 2, pasture production on the untopdressed area dropped from 97 per cent in the first year to 85 per cent in the fifth year and remained at about the latter figure for the next two years.

The soil test on untreated plots fell appreciably in the first year and gradually declined in the subsequent years. The total drop in seven years was about $5 \mathrm{P}$ units. The soil test on treated plots was raised to $15 \mathrm{P}$ units by five annual applications of 6 cwt/acre superphosphate and maintained at that level by the following two annual dressings. 
RELATIVE YIELD
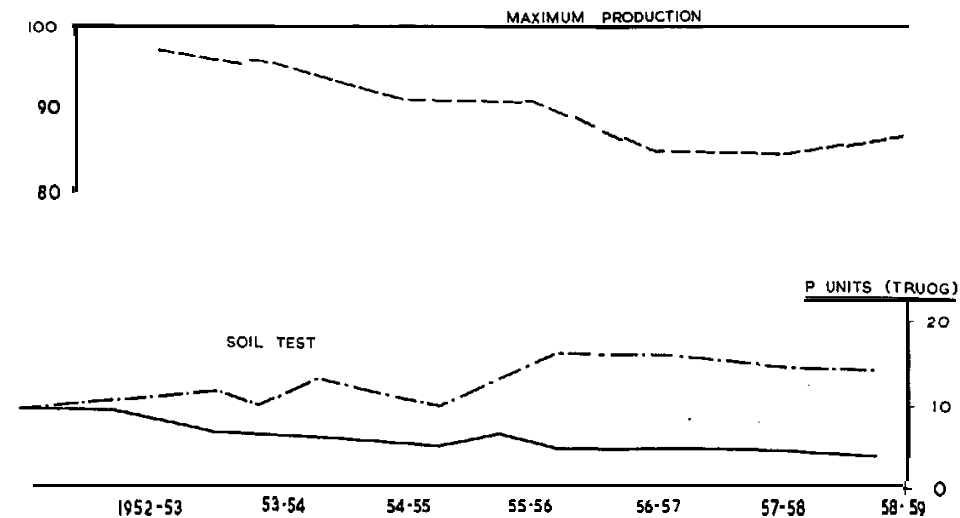

Fig. 2. ---- Annual pasture production on Ohaupo silt loam after the cessation of topdressing relative to maximum production equal to 100 . _ Soil test for phosphorus on plots on which topdressing has been discontinued.

$\because-$ Soil test for phosphorus on plots with maximum yield.

Trial 3: This trial began in 1953 on Horotiu sandy loam, which is noted for its high phosphate fixing capacity. Pasture production was measured by the "mowing and clippings returned" technique (Lynch). To investigate the residual effect of varying amounts of phosphate, the following four treatments of superphosphate were applied: $64 \mathrm{cwt} /$ acre over two years, and 48, 24, and $12 \mathrm{cwt}$ over a period of three years. Control plots were also included. The maximum production was attained by $64 \mathrm{cwt} / \mathrm{acre}$ superphosphate applied in the first two years and maintained by $4 \mathrm{cwt} / \mathrm{acre}$ annual applications in the subsequent years.

The residual effect from $64 \mathrm{cwt}$ was very marked for four successive years. The pasture production declined in a straight line from 96 to 93 per cent of the maximum; that is, only 1 per cent annually (Fig. 3). The residual effect from $48 \mathrm{cwt}$ sunerphosphate was substantial-97 per cent in the first year-but in the second and third year production decreased considerably to about 90 per cent of the maximum. Pasture production on soils treated with $24 \mathrm{cwt}$ superphosphate declined rapidly from 89 in the first year to 76 per cent of the maximum in the third year. The residual effect from $12 \mathrm{cwt}$ declined very severely and at the end of the third year was practically nil, with yields similar to the control.

The fall in soil test status on soils treated with $64 \mathrm{cwt}$ was very severe in the first' two years. It is usual to find that soils treated with heavy quantities of phosphate show very high levels for a certain time after the topdressing. In the following years the soil 


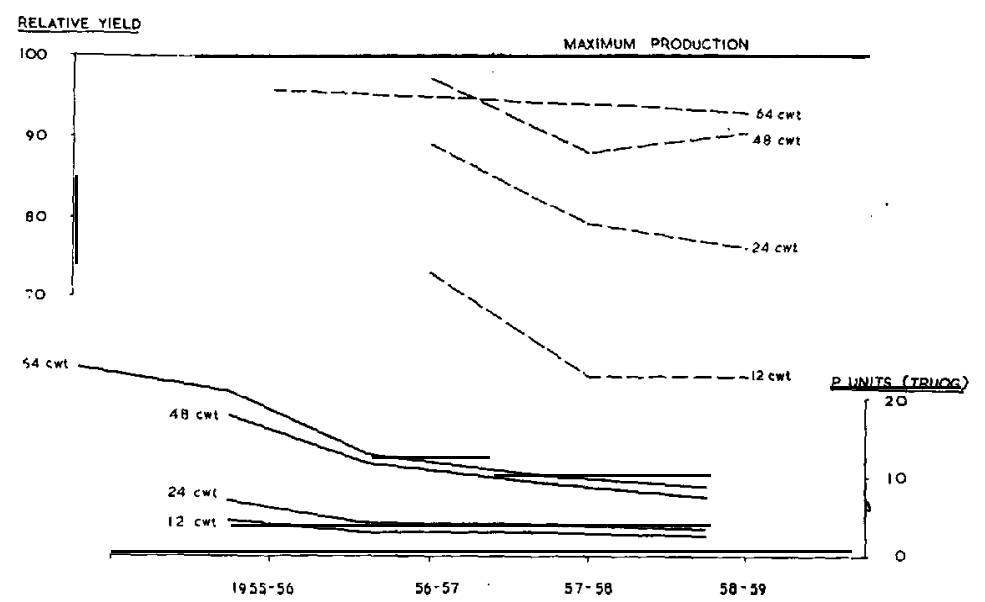

Fig. 3. Annual pasture production on Horotiu sandy loam after the cessation of topdressing on soils which received $64 \mathrm{cwt}$ superphosphate in two years and 48, 24, and 12 cwt superphosphate in three years relative to maximum production and the soil test levels on these soils.

test declined slowly. Similarly, on soils treated with 48,24 , and $12 \mathrm{cwt}$ the soil tests fell appreciably in the first year.

The phosphate residual effect from heavy applications is large and may last for many years, but there is a gradual decline in pasture production; that is, a decrease in the residual effect, and at a certain stage this may become severe, especially on high fixing soils. After the cessation of topdressing approximately 90 per cent of the maximum pasture production can be attained at a level of $6 \mathrm{P}$ units on Hamilton clay loam and Ohaupo silt loam and at about $9 \mathrm{P}$ units on Horotiu sandy loam.

II. The Residual Effect of Superphosphate on Pasture Production (a) After the Cessation of Topdressing; (b) After Continued Topdressing with a Basic Rate of $4 \mathbf{c w t} /$ acre Superphosphate on Soils with Different Manurial Histories

These comparisons have been made in trial No. 3 on Horotiu sandy loam described above. Fig. 4 shows the annual pasture dry matter increases above_control from the residual effect of 12,24 , and $48 \mathrm{cwt} /$ acre superphosphate dressings applied in three years. With increasing amounts of superphosphate there was an appreciable increase in pasture yield. Pasture production on $12 \mathrm{cwt}$ treated soils fell rapidly to the control level, while on soils treated with heavier dressings a big margin above control production was still being maintained four years after the last topdressing.

When dressings of $4 \mathrm{cwt} / \mathrm{acre}$ superphosphate were applied 

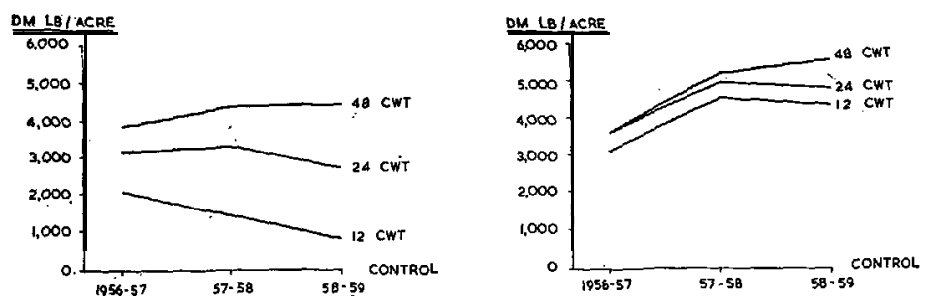

Fig. 4. The residual effect from varying amounts of superphosphate on annual pasture production after the cessation of topdressing.

Fig. 5. The residual effect from varying amounts of superphosphate on annual pasture production after continued annual topdressings with $4 \mathrm{cwt}$ superphosphate.

annually on the above plots with different manurial histories (that is, 12, 24, and $48 \mathrm{cwt}$ superphosphate, Fig. 5), the differences between the treatments were much smaller than after the cessation of topdressing. Thus, for instance, the average annual differences between 12 and 24 and 24 and 48 cwt superphosphate were respectively 1,670 and $1,140 \mathrm{lb}$ dry matter after the cessation of topdressing and only 450 and $320 \mathrm{lb}$ dry matter when the topdressing was continued. This is due to the fact that the response from fresh applications is much greater on lightly than on heavily treated soils. Fig. 6 shows total responses from three annual dressings of $4 \mathrm{cwt}$ superphosphate on soils previously treated with 12, 24, and $48 \mathrm{cwt}$ superphosphate. If the responses on 12 cwt treated soils equal 100, those on 24 and $48 \mathrm{cwt}$ soils are only 54 and 23 respectively.

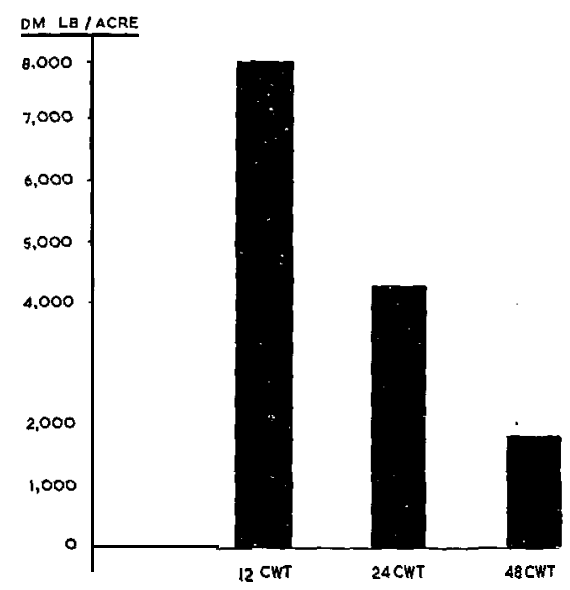

Fig. 6. The effects from three annual applications of $4 \mathrm{cwt}$ super-phosphate on pasture production on soils previously treated with 12,24 , and 48 cwt superphosphate. 
The soil test level for phospnorus on plots where the topdressing was stopped decreased gradually, while on soils treated with fresh applications of $4 \mathrm{cwt}$ superphosphate the soil status was maintained.

The above results indicate that the utilisation of superphosphate residues when fertilising continues is smaller, but may last longer, than when the topdressing is stopped.

III. The Effectiveness of 12, 24, and $48 \mathrm{cwt} /$ acre Superphosphate Applied in Equal Annual Dressings (a) Over the First Three Years of a Six-year Period, (b) Over the Six Years

In Fig. 7 the effects of three annual dressings of $4 \mathrm{cwt} / \mathrm{acre}$ superphosphate applied in 1953, 1954, and 1955, and the effects of six annual dressings of 2 cwt/acre applied in 1953-58 are compared. In the first three years $4 \mathrm{cwt}$ dressings yielded consistently better than $2 \mathrm{cwt}$ treatments. The yield differences were higher from year to year and in the third year they reached about 10 per cent. However, in the fourth year $2 \mathrm{cwt}$ treated soils yielded already slightly more. In the fifth and sixth year the latter soils yielded more by 25 and 32 per cent respectively. On the basis of the total six yearly production, $2 \mathrm{cwt}$ dressings yielded 7 per cent more.

At the end of the third year the soil test for phosphorus was slightly higher on the $4 \mathrm{cwt}$ treated plots, but it fell below the level of the $2 \mathrm{cwt}$ treatment in the fifth year.
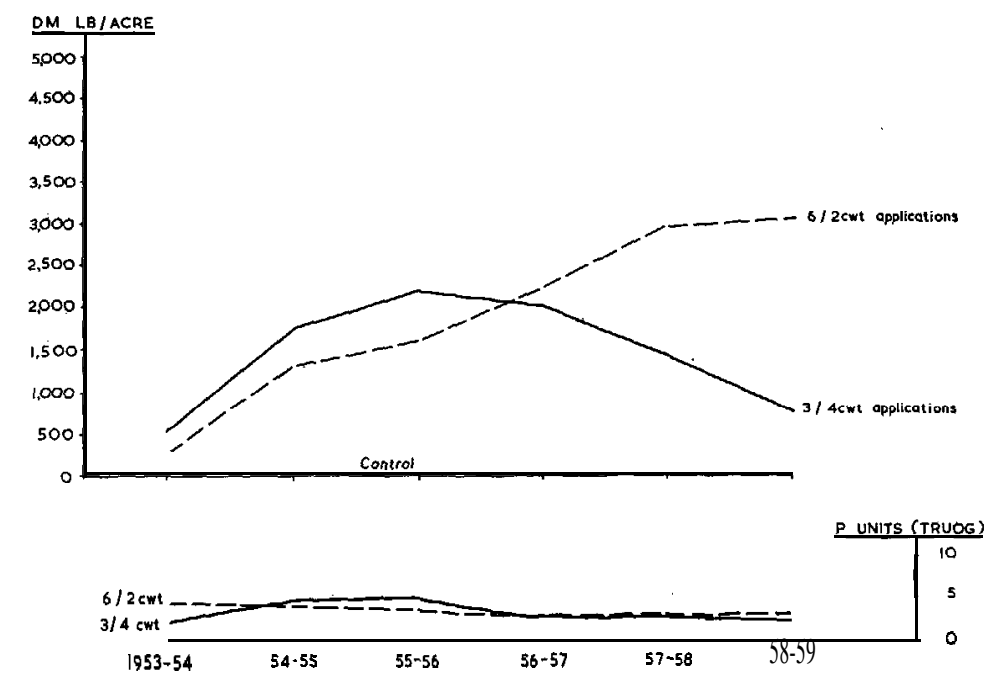

Fig. 7. Comparison between six $2 \mathrm{cwt}$ annual applications and three $4 \mathrm{cwt}$ applications of superphosphate applied in the first three years, as measured by pasture production and soil test. 
In Fig. 8 the effects from $24 \mathrm{cwt}$ superphosphate applied in two different ways (in three $8 \mathrm{cwt}$ and six $4 \mathrm{cwt} /$ acre dressings) are compared. Again in the first three years heavier dressings yielded consistently above lighter ones. In the fourth year both treatments yielded similarly, but in the fifth and sixth year the

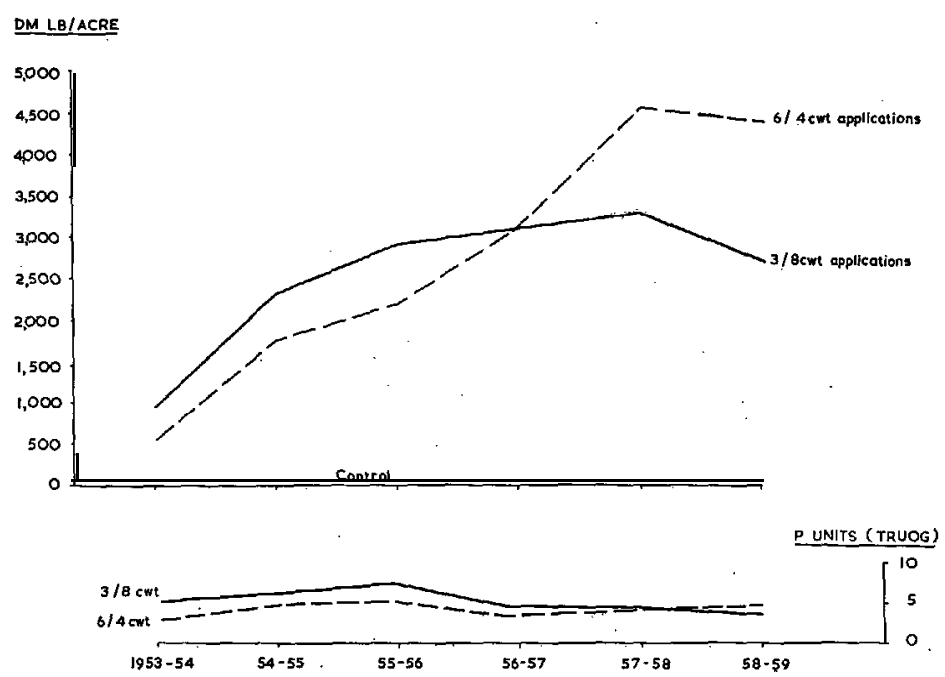

Fig. 8. Comparison between six $4 \mathrm{cwt}$ annual applications and three $8 \mathrm{cwt}$ applications of superphosphate applied in the first three years as measured by pasture production and soil test.

lighter dressings applied annually yielded 16 and 19 per cent more respectively. The total six yearly production was about 3 per cent higher on soils treated annually.

The soil test for phosphorus on $8 \mathrm{cwt}$ soils was higher for five years. In the sixth year it fell below the level of annually treated plots.

In Fig. 9 the effects from $48 \mathrm{cwt}$ superphosphate applied in the above two different ways are shown. Soils which received the whole quantity of fertiliser in the first three years yielded slightly more for four years. In the last two years, however, soils treated annually produced about 10 per cent more. Over the six-year period the production on the latter soils was 1 per cent higher.

The soil test for phosphorus on annually treated plots was considerably below the level on the other plots until the sixth annual application of $8 \mathrm{cwt}$ superphosphate, after which the position was reversed.

The above comparison over a six-year period does not, however, demonstrate fully the superiority of annual dressings, since 
at the end of that time the soil test level was slightly higher, from .6 to $1.8 \mathrm{P}$ units on annually treated plots. Though these differences may seem quite small, the differences in pasture production, from 10 to 30 per cent in the last year, suggest that the higher

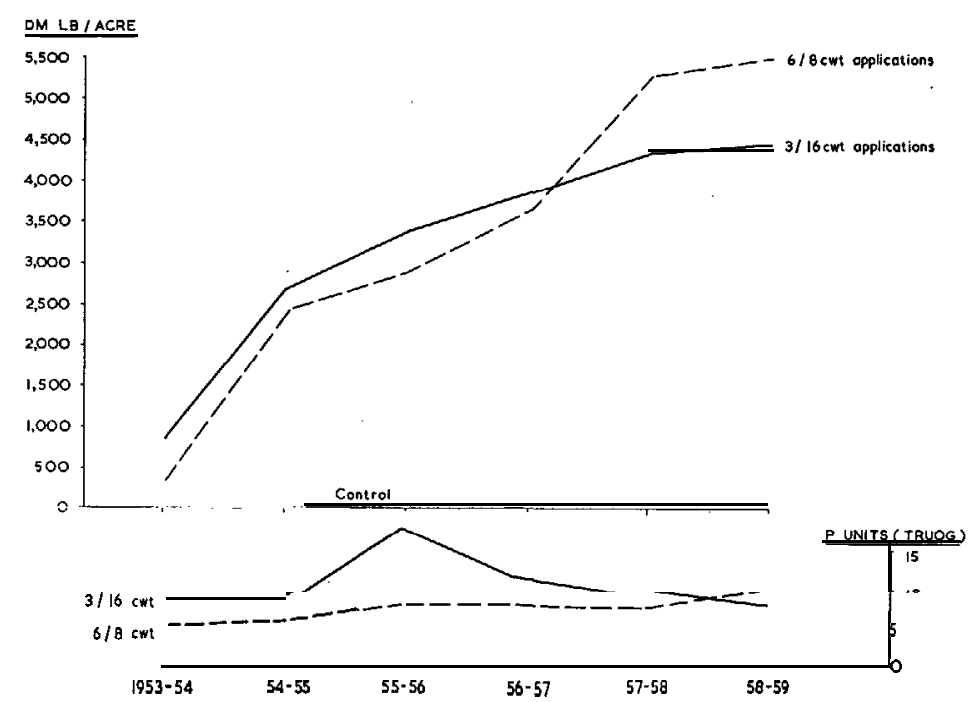

Fig. 9. Comparison between six $8 \mathrm{cwt}$ annual applications and three $16 \mathrm{cwt}$ applications of superphosphate applied in the first three years as measured by pasture production and soil test.

production on these plots might have persisted for quite a long period. These results show that a given quantity of superphosphate is more effective when applied annually, in equal amounts, than when the same total quantity is applied over a shorter period.

\section{The Residual Effect of the Same Quantities of Double Superphosphate on Two Soils}

The residual effects from 20 and 30 cwt/acre double superphosphate on seasonal dry matter production of pasture are being studied on low testing (3-4 P units) Hamilton clay loam and Horotiu sandy loam. At the same time the effects of the above quantities are being compared with the effects of smaller initial applications, plus varying amounts applied annually.

Pasture production in the Waikato fluctuates very much with the season. On low testing untopdressed soils the spring production is three to five times as high as the winter production, and as high as summer and autumn production together. The residual effect from the above heavy phosphatic applications changes this unfavourable seasonal distribution of pasture production very 
little on Hamilton clay loam, bui very appreciably on Horotiu sandy loam. On the former soil the seasonal pasture dry matter increases due to the residual effect have been almost in direct proportion to the seasonal pasture production on low testing untopdressed soils; that is, spring increases were about three times those in winter and considerably higher than either summer or

\section{DM LB /ACRE}

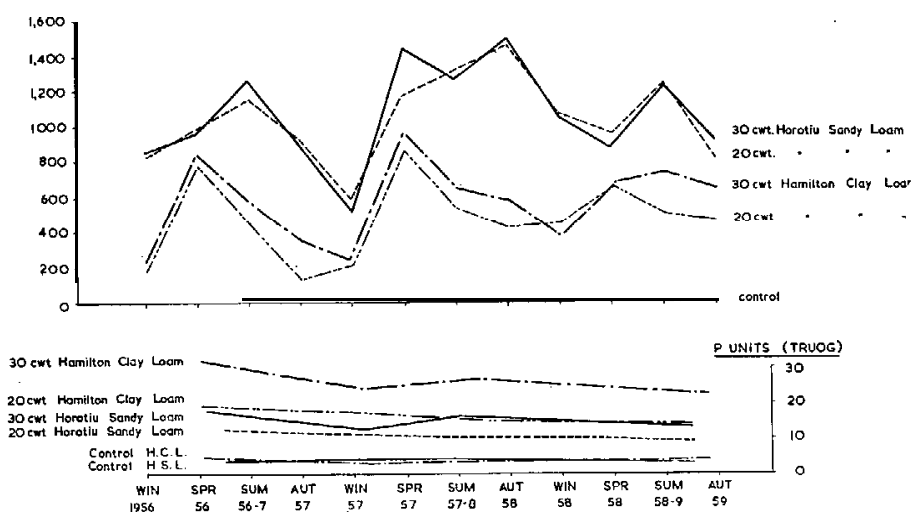

Fig. 10. Residual effect from 20 and $30 \mathrm{cwt}$ double superphosphate on seasonal pasture production and soil test on (a) Hamilton clay loam and (b) Horotiu sandy loam.

autumn ones (Fig. 10). On the other hand the ratio of seasonal increases from the residual effect on Horotiu sandy loam have been $2: 23: 3: 2 \frac{1}{2}$ for winter, spring, summer, and autumn. This is very different from the seasonal production on \&topdressed soils, which was five times higher in spring than in winter. This is no doubt due to the changes in the botanical composition of the sward which take place after the addition of phosphate.

Water-soluble phosphatic fertilisers are most effective for about six months after topdressing, irrespective of the time of application. After this time the effectiveness declines due to the fact that the fertiliser phosphorus gets more and more in contact with the soil, until finally the whole amount applied becomes possibly as strongly fixed by the soil as the original soil phosphorus. From then on the residues from applied phosphorus are relatively no more available than the rest of the soil phosphorus reserves. If we measured the residual effect of added phosphate on pastures by pure species, or under no change in the botanical composition of the sward, the seasonal residual increases should be directly proportional to the seasonal production on untreated soils, as is almost the case on Hamilton clay loam. If, however, changes in species are induced, as is the case on Horotiu sandy loam, then 
the phosphate residual effect becomes complicated by two factors: (a) change of species and (b) extra nitrogen assimilated by the increased amount of clovers, and the whole seasonal pasture growth pattern is changed. In absolute figures (lb dry matter per acre), the average residual effect over the three-year period on Horotiu sandy loam was twice as high as on Hamilton clay loam.

The average seasonal increases on the former soil type were only one-third higher in spring, but more than twice as high in summer and autumn, and three times higher in winter.

The soil test for phosphorus was built up to a very high level on Hamilton clay loam; that is, to 19 and $32 \mathrm{P}$ units respectively on soils treated with 20 and $30 \mathrm{cwt}$ double super. In three years' time the test declined gradually by 6 and $9 \mathrm{P}$ units respectively. On Horotiu sandy loam the soil test levels were raised to a much lower extent (to 12.5 and 17.5 units respectively), and these declined to 9 and 13 units over a three-year period.

\section{The R esidual Effect of Different Phosphatic Fertilisers}

The availability of residual phosphorus from different phosphate carriers was studied over a short time on Hamilton clay loam. Superphosphate was compared with North African phosphate, Nauru rock phosphate, serpentine superphosphate, super compound, and oxalic superphosphate on an equal weight basis. It was thought that the residual effect from rock phosphates, which on an equal weight basis supply considerably more phosphorus, would be greater than that from superphosphate. However, the results showed clearly that the efficacy of rock phosphates and other phosphatic fertilisers relatively to superphosphate after the cessation of topdressing was about the same as during the time of their annual applications. Fig. 11 shows the seasonal produc-

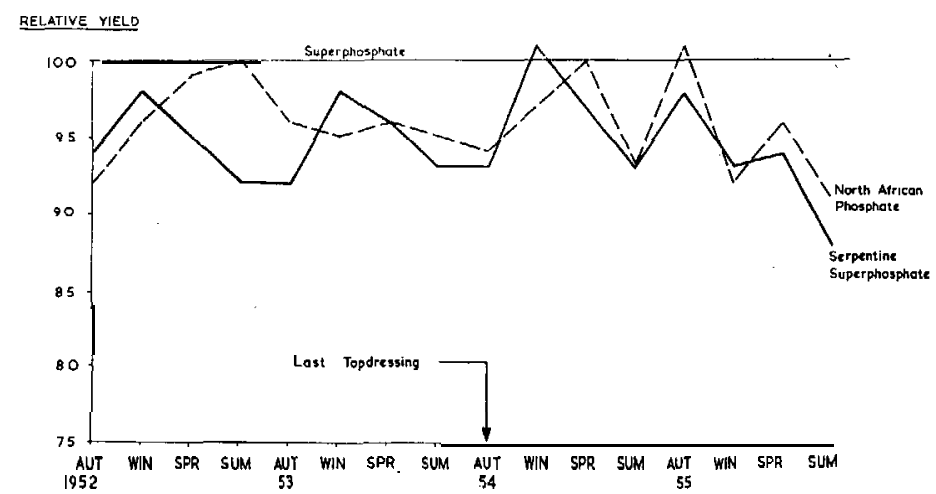

Fig. 11. Comparisons between superphosphate, North African phosphate, and serpentine superphosphate (applied on equal weight basis) during the period of annual topdressings as well $a^{*}$ after the last topdressing. 
tion from North African phosphate and serpentine superphosphate relatively to superphosphate $=100$, during the time of annual topdressings (autumn 1952, 1953, and 1954), as well as several seasons after the last topdressing in autumn 1954. Neither of the above fertilisers improved its position reiative to superphosphate in the last year 1955-56.

The soil test for phosphorus as determined by the Truog extractant showed much higher figures on plots treated with rock phosphates than on other plots. This is a common phenomenon on soils treated with rock phosphates and interpretation of soil tests on such soils is not reliable unless the amount of rock phosphate applied is known.

\section{Summary}

1. The residual effect of heavy applications of phosphatic fertilisers is large and may last for many years.

2. There is, however, a gradual decline in pasture production; that is, a decrease in the residual effect, and at a certain stage this may become severe, especially on high fixing soils.

3. About 90 per cent of the maximum pasture production can be obtained on Hamilton clay loam and Ohaupo silt loam testing six units and on Horotiu sandy loam testing nine units without additional topdressing.

4. A given quantity of superphosphate applied in equal amounts annually is more effective than the same total quantity applied over a shorter period, because fresh applications are more effective than residues from past applications.

5. In an extensive trial on Horotiu sandy loam under continuous annual topdressing the response from phosphate residues was about 35 times smaller than after cessation of topdressing.

6. The residual effect from the same quantities of double superphosphate on Horotiu sandy loam is twice that on Hamilton clay loam. While on the latter soil the biggest seasonal pasture increases from residual phosphate are obtained in spring, on Horotiu sandy loam summer increases are the highest.

7. Equal quantities of double superphosphate raised the soil test to a much higher level on Hamilton clay loam than on Horotiu sandy loam.

8. The residual effects from rock phosphates and other phosphatic fertilisers, applied on an equal weight basis, are smaller than that from superphosphate.

\section{REFERENCE}

Lynch, P. B. (1947) : Methods of Measuring the Production from Grasslands, N.Z. J. Sci. Tech. A28: 385-405. 


\section{DISCUSSION}

Q. (Mr C. J. Hamblyn): Do Mr Karlovsky's findings for three Waikato soils apply to soils in other districts and does the Department of Agriculture intend to extend this work to other soils?

A. The reported results may apply to similar soils under similar climatic and managerial conditions. It is intended to extend this work to other soil types.

Q. (Mr J.W. Woodcock): In view of the decrease in response to phosphate six months after application, is it disadvantageous for the hill country farmer to extend the time of application from autumn to other seasons, as requested by the aerial topdressing firms?

A. Water soluble phosphate is most effective for the six months after application, but the decline in effectiveness is not very serious in the subsequent months. For the highest autumn and winter production on Waikato low lands, phosphate should be applied in autumn. However, the seasonal distribution of pasture production and the responses might be quite different on hill country, and it can be stated that the time of application is not so important on these soils and one should aerially topdress when the services of the topdressing firm are available.

Q. (Mr Pantall): Why do you use such very heavy applications?

A. Heavy applications of phosphate are essential for the study of residual effects, especially on high phosphate fixing soils. However, we always compare these heavy dressings with standard applications of 2,3 or 4 cwt per acre.

Q. (Mr 1. L. Elliott): What is the effectiveness of splitting the annual application of phosphate in comparison with single dressings?

A. Splitting the application over autumn and spring has not proved to give better results than a single autumn dressing. Split applications have given a better increase in production in spring and summer. However, this increase has not fully compensated for the loss in production in autumn and winter.

Q. (Mr G. K. McPherson): Would the same response be obtained from applications in January or February as from March applications, and similarly would applications in June or July be as good as August dressings? This would be of great importance for the aerial topdressing industry, as farmers have always insisted on March and August applications.

A. The time of application is, in general, of only minor importance, when the total annual responses are considered. If there is no growth in January and February (dry summer), topdressing during these months may give similar responses to that in March. Phosphate applied in a wet summer will increase summer production, but the responses in the subsequent seasons will be smaller than those from March topdressing.

June or July applications may be as effective as August ones in districts with , winter growth. However, in districts where there is no June or July growth, it may be advisable to postpone topdressing until the commencement of the growth, especially in areas with heavy rainfall.

Q. (Mr Holland): (a) Did you follow up your very heavy application's with low annual rates? (b) Would the splitting of annual applications be beneficial after the soil phosphorus level has been built up?

A. (a) On some plots topdressing was discontinued, while on other plots rates of $4 \mathrm{cwt} /$ acre annually followed heavy dressings. (b) No, a single autumn application is preferable as it gives the best seasonal distribution of pasture responses. 